Volume 19 Nomor 2

\title{
PERBANDINGAN PENERIMAAN PENDAPATAN ASLI DAERAH PADA BADAN PAJAK DAN RETRIBUSI DAERAH KOTA MEDAN TAHUN ANGGARAN 2016-2018
}

\author{
Mario Nicolas Munthe \\ Staff BPS Papua Barat Jl. Trikora Sowi IV No. 99, Manokwari - Papua Barat 98315 Indonesia, \\ email: mario.munthe@bps.go.id
}

\begin{abstract}
The purpose of this study was to analyze the comparison of the original regional revenue in the Tax Agency and Regional Retribution of Medan City for the 2016-2018 fiscal year. The data used is secondary data obtained from the Regional Financial and Asset Management Agency of Medan City. The analytical tool used is the percentage comparison analysis. The results showed that for: (a) for the 2017/2016 fiscal year showed that the realization of regional tax increased by 24.22 percent, regional retribution decreased by 2.03 percent, revenue from the management of separated weal th areas decreased by 31, 88 percent, and other legitimate local revenues decreased by 25.72 percent. (b) for the fiscal year $2018 / 2017$ shows that the realization of regional tax has decreased by 6.27 percent, regional retribution has decreased by 24.76 percent, income from the management of separated regional weal th has increased by 95.26 percent, and others- other legitimate local revenues increased by 8.39 percent
\end{abstract}

Keywords: Regional tax, regional retribution, revenue from separated regional wealth management and other legitimate local revenue.

\section{PENDAHULUAN}

Sesuai dengan amanat Undang Undang Nomor 23 Tahun 2014 tentang Pemerintahan Daerah, memberi wewenang kepada daerah untuk mengatur dan mengurus masyarakatnya sendiri sesuai Pelaksanaan Otonomi Daerah. Dalam menjalankan wewenang tersebut, Pemerintah Daerah dituntut untuk berupaya meningkatkan pendapatan daerah guna membiayai penyelenggaraan pemerintahan.Semenjak system otonomi daerah diberlakukan pada awal januari 2001, otonomi daerah menjadi hal yang penting dalam pelaksanaan pembangunan daerah, dikarenakan setiap daerah harus mampu mengelola sumber sumber pendapatan daerah guna membiayai pengeluaran pemerintah. Peran pemerintah daerah juga sangat diperlukan guna mengetahui dana yang diperlukan untuk meningkatkan pembangunan daerahnya karena pemerintah daerahlah lebih mengetahui kondisi daerahnya. Menurut asas otonomi bahwa penyelenggaran otonomi daerah diarahkan untuk mempercepat terwujudnya kesejahteraan masyarakat melalui peningkatan pelayanan,

Pemerintah Pusat memiliki hubungan keuangan dengan Daerah untuk membiayai penyelenggaraan Urusan Pemerintahan yang diserahkan dan/atau ditugaskan kepada Daerah. Peraturan tentang penyelenggaraan pemerintahan daerah pengaturannya terdapat dalam Undang-Undang Nomor 23 Tahun 2014 tentang Pemerintahan Daerah, undangundang ini memberikan kewenangan dibidang pemerintahan yang sangat luas kepada daerah.

Fungsi dan kewenangan Pemerintah Daerah dalam bentuk pelaksanaan kewenangan harus dapat mengenali potensi dan mengidentifikasi sumber-sumber daya yang dimilikinya. Pemerintah Daerah diharapkan lebih mampu menggali sumber-sumber keuangan khususnya untuk memenuhi kebutuhan pembiayaan pemerintahan di daerahnya melalui Pendapatan Asli Daerah (PAD). PAD merupakan pendapatan daerah yang bersumber dari hasil pajak daerah, hasil retribusi daerah, hasil pengelolaan kekayaan daerah yang dipisahkan, dan lainlain pendapatan asli daerah yang sah, yang bertujuan untuk memberikan keleluasaan kepada daerah dalam menggali pendanaan dalam pelaksanaan otonomi daerah sebagai perwujudan asas desentralisasi. 


\section{Volume 19 Nomor 2}

Pemberian otonomi yang seluas-luasnya kepada daerah diarahkan untuk mempercepat terwujudnya kesejahteraan masyarakat melalui peningkatan pelayanan, pemberdayaan, dan peran serta masyarakat. Di samping itu melalui otonomi luas, dalam lingkungan strategis globalisasi, daerah diharapkan mampu meningkatkan daya saing dengan memperhatikan prinsip demokrasi, pemerataan, keadilan, keistimewaan dan kekhususan serta potensi dan keanekaragaman daerah dalam sistem Negara Kesatuan Republik Indonesia.Pemberian otonomi luas kepada daerah diarahkan untuk mempercepat terwujudnya kesejahteraan masyarakat melalui peningkatan pelayanan, prestasi kerja, pemberdayaan dan peran serta masyarakat.

Sumber-sumber penerimaan daerah yang potensial harus digali secara maksimal didalam koridor peraturan perundang-undangan yang berlaku, termasuk diantaranya adalah Pajak Daerah dan Retribusi Daerah yang sudah sejak lama menjadi salah satu unsur Pendapatan Asli Daerah yang utama. Kehadiran Undang-Undang Nomor 28 Tahun 2009 tentang Pajak Daerah dan Retribusi Daerah telah membuka peluang sebesar-besarnya kepada daerah dalam hal pengelolaan Pendapatan Asli Daerah. Pendapatan Asli Daerah merupakan sumber pembiayaan yang paling penting dimana komponen utamanya adalah penerimaan yang berasal dari komponen pajak daerah dan retribusi daerah.

Semakin tinggi kewenangan keuangan yang dimiliki daerah, semakin tinggi peranan Pendapatan Asli Daerah dalam struktur keuangan daerah, begitu pula sebaliknya. Pengelolaan keuangan daerah sebagaimana dimaksud dilakukan secara tertib, taat pada ketentuan peraturan perundang-undangan, efisien, ekonomis, efektif, transparan, dan bertanggung jawab dengan memperhatikan rasa keadilan, kepatutan, dan manfaat untuk masyarakat.Ini sangat penting dalm hal Pengelolaan Pendapatan Asli Daerah Kota Medan yang dijalankan oleh Badan Pengelola Pajak dan Retribusi Daerah Kota Medan.

Sejalan dengan perubahan Undang-Undang otonomi daerah tersebut, tentunya membawa konsekuensi kepada perubahan dalam pengelolaan fiskal pemerintah daerah.Perubahan ini membuat pemerintah daerah diharapkan lebih mampu melaksanakan pembangunan di segala bidang, terutama untuk pembangunan sarana dan prasarana publik.Pembangunan tersebut diharapkan dapat dilaksanakan secara mandiri baik dari sisi perencanaan, pembangunan, maupun pembiayaan.

Tujuan utama ditetapkannya Undang HUndang otonomi tersebut bukan hanya keinginan untuk melimpahkan kewenangan pembangunan dari Pemerintah Pusat ke Pemerintah Daerah, tetapi yang lebih penting adalah efisiensi dan efektivitas sumber daya keuangan.Untuk itu di perlukannya upaya agar kinerja keuangan pemerintah handal dan dapat di percaya.Agar kinerja keuangan pemerintah menggambarkan sumber daya keuangan daerah, tersebut, maka diperlukan analisis prestasi pengelolaan sumber daya keuangan daerah.Hal tersebut sesuai dengan ciri penting dari suatu daerah otonom yang mampu menyelenggarakan otonomi daerahnya yaitu terletak pada strategi sumber daya manusia dan kemampuan di bidang keuangan daerah.

Pengelolaan keuangan daerah yang baik akan berpengaruh terhadap kemajuan suatu daerah. Sebab pengelolaan keuangan daerah sangat besar pengaruhnya terhadap nasib suatu daerah karena daerah dapat menjadi daerah yang kuat serta mampu berkembang atau tidak, tergantung pada cara mengelola keuangannya. Pengelolaan keuangan daerah yang baik akan membuat aset daerah terjaga juga keutuhannya. Pengelolaan keuangan daerah yang baik tidak hanya membutuhkan sumberdaya manusia yang handal tetapi juga harus didukung oleh kemampuan keuangan daerah yang memadai.

Pemberian hak otonomi daerah kepada pemerintah daerah untuk menentukan Anggaran Pendapatan dan Belanja Daerah sendiri sesuai dengan kebutuhan dan potensi daerah, mempertegas semakin diperlukannya pengelolaan keuangan yang baik dan benar, untuk melihat seberapa baik dan benarnya suatu pengelolaan keuangan maka perlu 


\section{Volume 19 Nomor 2}

dilakukan pengukuran kinerja keuangan. Menurut Jumingan (2006) pengukuran kinerja keuangan memiliki dua tujuan.Pertama pengukuran kinerja keuangan digunakan untuk mengetahui keberhasilan pengelolaan keuangan.Kedua untuk mengetahui kemampuan dalam mendayagunakan semua aset.Pengukuran kinerja keuangan sangat penting untuk menilai akuntabilitas pemerintah daerah dalam melakukan pengelolaan keuangan daerah. Akuntabilitas bukan sekedar kemampuan menunjukkan bagaimana uang publik dibelanjakan, akan tetapi meliputi kemampuan yang menunjukkan bahwa uang publik tersebut telah dibelanjakan secara efisien, efektif, dan ekonomis. Efisien berarti penggunaan dana masyarakat tersebut menghasilkan output yang maksimal, efektif berarti penggunaan anggaran tersebut harus mencapai target-target atau tujuan untuk kepentingan publik, dan ekonomis berkaitan dengan pemilihan dan penggunaan sumber daya dalam jumlah dan kualitas tertentu pada tingkat harga yang paling murah (Mardiasmo,2004).

Selama ini penyusunan Anggaran Pendapatan dan Belanja Daerah masih dilakukan berdasarkan pertimbangan incremental budget maka seringkali mengabaikan kinerja keuangan dalam Anggaran Pendapatan dan Belanja Daerah. Anggaran pendapatan seringkali dibuat lebih kecil dari potensi pendapatan yang mungkin didapat agar pada tahap pelaporan realisasi anggaran diharapkan realisasi pendapatan lebih besar jumlahnya dari anggaran pendapatan yang telah dibuat, sedangkan belanja memiliki sifat yang relatif mudah dilakukan dan rentan akan terjadinya inefisiensi dan kebocoran sehingga kemungkinan anggaran belanja dibuat lebih besar dari potensi realisasi belanja yang sebenarnya. Penggunaan analisis kinerja keuangan sebagai alat keuangan secara luas sudah diterapkan pada lembaga perusahaan yang bersifat komersial sedangkan pada lembaga publik khususnya pemerintah daerah masih sangat terbatas. Maka itu perlu suatu perubahan yang mengacu pada penggunaan analisis kinerja keuangan dalam pengukuran kinerja keuangan pemerintah daerah

Menilai kinerja keuangan pemerintah daerah dapat dilakukan dengan cara melihat kinerjanya melalui laporan realisasi anggaran. Laporan realisasi anggaran menggambarkan perbandingan antara anggaran dengan realisasinya dalam suatu periode pelaporan. Laporan realisasi anggaran juga menyediakan informasi yang beguna dalam memprediksi sumber daya ekonomi yang akan diterima untuk mendanai kegiatan pemerintah daerah dalam periode mendatang dengan cara menyajikan laporan secara komparatif. Berdasarkan latar belakang diatas, maka rumusan masalah dalam penelitian ini adalah :Bagaimana perubahan penerimaan Pajak Daerah dan Retribusi Daerah Kota Medan Tahun Anggaran 2016-2018.

\section{TINJAUAN PUSTAKA}

\section{A. Kebijakan Otonomi Daerah}

Kebijakan yang menggeser dominasi penyelenggaraan pemerintahan dari pusat ke daerah adalah kebijakan otonomi daerah.Pergeseran ini memberikan peluang dan sekaligus tantangan bagi daerah untuk meningkatkan kualitas penyelenggaraan kepemerintahaanya serta meningkatkan akselerasi pembangunan didaerahnya. Tujuan umum dari kebijakan otonomi daerah/desentralisasi sebagaimana tersirat dalam Undang-Undang No.23 Tahun 2014 adalah:

a. Memberi peluang dan kesempatan bagi terwujudnya pemerintah yang baik dan bersih (clean and good governance) di daerah dalam pelayanan publik, yang berarti pelaksanaan tugas pemerintah daerah harus didasarkan atas prinsip : efektif, efisien, terbuka, dan akuntabel.

b. Meningkatkan kesejahteraan rakyat dengan selalu memperhatikan kepentingan dan aspirasi yang tumbuh dalam masyarakat; 


\section{Volume 19 Nomor 2}

c. Menjamin keserasian hubungan antara daerah satu dengan daerah lainnya, artinya mampu membangun kerjasama antar daerah dengan daerah lainnya untuk meningkatkan kesejahteraan bersama dan mencegah ketimpangan antar daerah;

d. Menjamin hubungan yang serasi antara daerah dengan pemerintah, artinya harus mampu memelihara dan menjaga keutuhan wilayah Negara dan tetap tegaknya Negara Kesatuan Republik Indonesia dalam rangka mewujudkan tujuan Negara.

e. Meningkatkan daya saing daerah untuk mendukung ekonomi nasional.

Menurut Saragih (2003) bahwa salah satu tujuan dari kebijakan otonomi daerah/desentralisasi adalah memberdayakan masyarakat lokal (setempat) sehingga memungkinkan masyarakat lokal untuk dapat menikmati kualitas kehidupan yang lebih baik, maju, tenteram, dan sekaligus memperluas pilihan-pilihan (choices) yang dapat dilakukan masyarakat.Salah satu aspek yang mendukung berhasilnya kebijakan otonomi daerah (desentralisasi) adalah aspek ekonomi, yaitu perlunya dukungan sumberdaya yang memadai dan cukup. Untuk itu, dikeluarkanlah kebijakan desentralisasi fiskal yang bertujuan untuk meningkatkan "efektifitas" penyelenggaraan pemerintahan dan pelayanan publik, serta sebagai langkah untuk mendukung dan meningkatkan kemampuan keuangan pemerintah daerah dalam melaksanakan otonomi.

Desentralisasi fiskal merupakan suatu proses distribusi anggaran dari tingkat pemerintahan yang lebih tinggi kepada pemerintahan yang lebih rendah untuk mendukung fungsi atau tugas pemerintahan dan pelayanan publik sesuai dengan banyaknya kewenangan bidang pemerintahan yang dilimpahkan tergantung kepadadaerah yang bersangkutan sesuai dengan kreativitas, kemampuan organisasi pemerintahan daerahserta kondisi setiap daerah.

Dalam rangka pelaksanaan otonomi, tidak dapat dipungkiri bahwa dalam menjalankan implementasi otonomi sepenuhnya sangat diperlukan dana yang memadai. Oleh karena itu, melalui implementasi Undang-Undang Nomor 33 tahun 2004, diharapkan kemampuan daerah untuk memperoleh dana atau anggaran belanjanya dapat ditingkatkan seiring dengan peningkatan kebutuhan daerah. Sebagai daerah otonom, setiap daerah kabupaten/kotadituntut untuk dapat mengembangkan dan mengoptimalkan semua potensinya yang dapat digali dari wilayah daerah bersangkutan yang terdiri dari hasil pajak daerah, hasil retribusi daerah, pengelolaan kekayaan yang dipisahkan, dan lain-lain pendapatan asli daerah yang sah yang menjadi sumber PAD dalam kaitannya dengan pemenuhan kewajiban pemerintah untuk meningkatkan tingkat kesejahteraan rakyatnya serta menjaga dan memelihara ketentraman dan ketertiban masyarakat.Ciri utama suatu daerah mampu melaksanakan otonomi daerah adalah:

a. Kemampuan keuangan daerah, yang berarti daerah tersebut memiliki kemampuan dan kewenangan untuk menggali sumber-sumber keuangannya, mengelolah dan menggunakan keuangannya sendiri untuk membiayai penyelenggaraan pemerintahan di daerahnya masing-masing; dan

b. Ketergantungan kepada sumber keuangan terbesar yang didukung oleh kebijakan perimbangan keuangan pemerintah pusat dan daerah sebagai prasyarat dalam sistem pemerintahan negara. Dalam artian bahwa keberhasilan pengembangan otonomi daerah bisa dilihat dari derajat otonomi fiscal daerah, yakni perbandingan antara PAD dengan total penerimaan daerah dalam APBD yang semakin meningkat dari tahun ke tahun.

Penerimaan daerah yang tercermin dalam APBD berasal dari PAD, yaitu pajak daerah, retribusi daerah, bagian laba BUMD, penerimaan dari dinas-dinas dan penerimaan lain-lain, serta penerimaan dari bagi hasil bukan pajak, sumbangan dan bantuan, baik pemerintah pusat maupun dari pemerintah Provinsi sebagai atasannya serta penerimaan pembangunan berupa pinjaman daerah. Oleh karena itu, disamping proyek pemerintah pusat dan proyek pemerintah Provinsi yang berada di Kabupaten/Kota, terdapat pula proyek Kabupaten/Kota yang tercermin dalam APBD Kabupaten/Kota bersangkutan, dimana didalamnya terdapat 


\section{Volume 19 Nomor 2}

komponen PAD yang bebas dipergunakan oleh Kabupaten/Kota tersebut sesuai dengan skala prioritasnya. Bahkan peranan PAD Kabupaten/Kota dalam pembangunan daerah sangat penting, karena kadang-kadang diperlukan sebagai dana pendamping untuk proyek pusat. Hal ini sejalan dengan pendapat Mardiasmo (2004) bahwa di sisi penerimaan, kemampuan pemerintah daerah dalam meningkatkan penerimaan daerahnya secara berkesinambungan masih lemah.Bahkan masalah yang sering muncul adalah rendahnya kemampuan pemerintah daerah untuk meghasilkan prediksi penerimaan daerah yang sangat akurat, sehingga belum dapat dipungut secara optimal.

\section{B. Pendapatan Daerah}

Pada Pasal 23 Peraturan Menteri Dalam Negeri Nomor 13 Tahun 2006 Tentang Pedoman Pengelolaan Keuangan Daerah disebutkan bahwa pendapatan daerah meliputi semua penerimaan uang melalui rekening kas umum daerah, yang menambah ekuitas dana, merupakan hak daerah dalam satu tahun anggaran dan tidak perlu dibayar kembali oleh daerah.Sehubungan dengan hal tersebut, pendapatan daerah yang dianggarkan dalam APBD merupakan perkiraan yang terukur secara rasional yang dapat dicapai untuk setiap sumber pendapatan.Secara garis besar, sumber pembiayaan (pendapatan) ini dapat diklasifikasikan ke dalam dua kategori sumber pembiayaan, yakni: (1) pendapatan yang diperoleh pemerintah daerah dari sumber-sumber di luar pemerintah daerah (external source). Pendapatan ini merupakan pendapatan yang diperoleh dari -sumber yang berasal dari pihak luar dan tidak secara langsung ditangani sumber sendiri oleh pemerintah daerah. Pihak luar yang dimaksud adalah pihak-pihak yang berada di luar pemerintah daerah yang bersangkutan (selain pemerintah daerah beserta perangkatnya) dan bukan merupakan penduduk daerah yang bersangkutan, seperti pemerintah pusat, tingkatan pemerintahan yang ada di atas pemerintahan daerah yang bersangkutan, negara asing, pihak swasta, dan pihak ketiga; dan (2) pendapatan yang diperoleh pemerintah daerah dari sumber-sumber yang dikelola oleh pemerintah daerah itu sendiri (local source). Kategori pendapatan yang kedua ini merupakan pendapatan yang digali dan ditangani sendiri oleh pemerintah daerah dari sumber-sumber pendapatan yang terdapat dalam wilayah yurisdiksinya.Pendapatan yang termasuk ke dalam kategori pendapatan ini adalah pajak daerah (local tax, sub national tax), retribusi daerah (local retribution, fees, local đicence) dan hasil-hasil badan usaha (local owned enterprises) yang dimiliki oleh daerah.Ketiga jenis pendapatan ini merupakan pendapatan yang digali dan ditangani sendiri oleh pemerintah daerah dari sumber-sumber pendapatan yang terdapat dalam wilayah yurisdiksinya.

Pendapatan Daerah merupakan hak Pemerintah daerah yang diakui sebagai penambah nilai kekayaan bersih dalam periode yang bersangkutan.Semua barang dan jasa sebagai hasil dari kegiatan-kegiatan ekonomi yang beroperasi di wilayah domestik, tanpa memerhatikan apakah faktor produksinya berasal dari atau dimiliki oleh penduduk daerah tersebut, merupakan "Produk Domestik Regional Bruto" (PDRB) daerah bersangkutan.Pendapatan yang timbul oleh karena adanya kegiatan produksi tersebut merupakan "Pendapatan Regional". Selanjutnya, di dalam UU No 33 Tahun 2004 telah ditegaskan pula bahwa Sumber Pendapatan Daerah terdiri dari; a) Pendapatan Asli Daerah, b) Dana Perimbangan, c) Lain-lain penerimaan yang sah.

\section{Pendapatan Asli Daerah}

Menurut UU No 33 tahun 2004, Pendapatan Asli Daerah (PAD) adalah pendapatan yang diperoleh daerah yang dipungut berdasarkan peraturan daerah sesuai dengan peraturan perundang-undangan, terdiri dari :(a). Pajak daerah, (b) Retribusi daerah, (c) Hasil pengelolaan kekayaan daerah yang dipisahkan, (d) Lain-lain pendapatan asli daerah yang sah 


\section{Volume 19 Nomor 2}

Halim (2012) mengemukakan bahwa Pendapatan Asli Daerah (PAD) dapat dipandang sebagai salah satu indikator atau kriteria untuk mengukur tingkat ketergantungan suatu daerah kepada pemerintah daerah. Pada prinsipnya, semakin besar sumbangan PAD kepada APBD akan menunjukkan semakin kecilnya tingkat ketergantungan pemerintah daerah kepada pemerintah pusat. Dalam rangka implementasi Undang-undang Nomor 23 tahun 2014 dan Undang-Undang Nomor 33 tahun 2004, maka salah satu faktor yang harus dipersiapkan oleh pemerintah daerah adalah kemampuan keuangan daerah, sedangkan indikator yang dipergunakan untuk mengukur kemampuan keuangan daerah tersebut ialah rasio PAD dibandingkan dengan total penerimaan APBD.Dalam perkembangan selama ini terlihat bahwa diantara semua komponen Pendapatan Asli Daerah (PAD), maka pajak daerah dan retribusi daerah merupakan penyumbang terbesar, sehingga muncul anggapan bahwasanya Pendapatan Asli Daerah (PAD) identik dengan pajak daerah dan retribusi daerah. Oleh karena itu, dapat dilihat bahwa pada umumnya pemerintah daerah lebih cenderung untuk menggenjot secara optimal sumber-sumber PAD daerahnya yang diperoleh dari sumber pajak daerah dan retribusi daerah dibandingkan dengan sumber-sumber PAD lainnya, termasuk laba badan usaha milik daerah, meskipun sumber-sumber lainnya tersebut memiliki potensi yang sangat besar untuk dikembangkan di daerah bersangkutan.

\section{Pajak Daerah}

Di dalam UU No 28 tahun 2009 tentang Pajak Daerah dan Retribusi Daerah dinyatakan bahwa Pajak Daerah, yang selanjutnya disebut Pajak, adalah kontribusi wajib kepada daerah yang terutang oleh orang pribadi atau badan yang bersifat memaksa berdasarkan UndangUndang, dengan tidak mendapatkan imbalan secara langsungdan digunakan untuk keperluan daerah bagi sebesar-besarnya kemakmuran rakyat. Selanjutnya, di dalam UU nomor 28 tahun 2009 ditegaskan bahwa pajak kabupaten/kota dibagi menjadi beberapa jenis, yakni:
a. Pajak Hotel,
b. Pajak Restoran,
c. Pajak Hiburan,
d. Pajak Reklame,
e. Pajak Penerangan Jalan,
f. Pajak Mineral bukan Logam dan Batuan,
g. Pajak Parkir,
h. Pajak Air Tanah,
i. Pajak Sarang Burung Walet,
j. Pajak Bumi dan Bangunan Perdesaan dan Perkotaan, dan
k. Pajak Bea Perolehan Hak atas Tanah dan Bangunan.

\section{E. Retribusi Daerah}

Menurut UU Nomor 28 Tahun 2009 secara keseluruhan terdapat 30 jenis retribusi yang dapat dipungut oleh daerah yang dikelompokkan ke dalam 3 golongan retribusi, yaitu retribusi jasa umum, retribusi jasa usaha, dan retribusi perizinan tertentu

a. Retribusi Jasa Umum yaitu pelayanan yang disediakan atau diberikan pemerintah daerah untuk tujuan kepentingan dan kemanfaatan umum serta dapat dinikmati oleh orang pribadi atau badan. Jenis retribusi umum adalah; (a) Retribusi layanan kesehatan; (b) Retribusi pelayanan persampahan/kebersihan; (c). Retribusi penggantian biaya cetak KTP dan Akte catatan sipil; (d) Retribusi Pelayanan Pemakaman dan pengabuan mayat; (e) Retribusi pelayanan parkir tepi jalan umum; (f) Retribusi pelayanan pasar; (g) Retribusi pengujian kenderaan bermotor; (h) Retribusi pemeriksaan alat pemadam kebakaran; (i) Retribusi penggantian biaya cetak peta; (j) Retribusi penyediaan/penyedotan kakus; (k). 


\section{Volume 19 Nomor 2}

Retribusi pengelolaan limbah cair; (l) Retribusi pelayanan tera/tera ulang; (m) Retribusi pelayanan pendidikan; dan (n) Retribusi pengendalian Menara telekomunikasi.

b. Retribusi Jasa Usaha adalah pungutan daerah sebagai pembayaran atas jasa usaha yang khusus disediakan dan/atau diberikan oleh pemerintah daerah untuk kepentingan orang pribadi atau badan. Jenis retribusi jasa usaha yakni: (a) Retribusi pemakaian kekayaan daerah; (b) Retribusi pasar grosir/pertokoan; (c) Retribusi tempat pelelangan; (d) Retribusi Terminal; (e) Retribusi tempat khusus parkir; (f) Retribusi tempat penginapanan/pesanggeraan/ villa; (g). Retribusi rumah potong hewan; (h). Retribusi pelayanan kepelabuhan; (i). Retribusi tempat rekreasi dan oleh raga; (j). Retribusi penyeberangan air; dan (k). Retribusi Penjualan produksi usaha daerah.

c. Retribusi Perizinan Tertentu adalah pungutan daerah sebagai pembayarann atas pemberian izin tertentu yang khusus diberikan oleh pemerintah daerah untuk kepentingan orang pribadi atau badan. Jenis retribusi perizinan tertentu yakni; (a) Retribusi izin mendirikan bangunan; (b). Retribusi tempat penjualan minuman beralkohol; (c). Retribusi izin gangguan; (d) Retribusi Izin trayek; (e). Retribusi izin usaha perikanan. Pungutan pajak dan retribusi daerah yang berlebihan dalam jangka pendek dapat meningkatkan pendapatan asli daerah, namun dalam jangka panjang dapat menurunkan kegiatan perekonomian, yang pada akhirnya akan menyebabkan menurunnya pendapatan asli daerah. Hal ini sesuai dengan pendapat Mardiasmo 2002 yang menyatakan; Untuk kepentingan jangka pendek pungutan yang bersifat retribusi lebih relevan dibanding pajak. Alasan yang mendasari, pungutan ini secara langsung berhubungan dengan masyarakat

\section{F. Hasil Pengelolaan Kekayaan Daerah Yang Dipisahkan.}

Undang-Undang Nomor 33 tahun 2004 mengklasifikasikan jenis hasil pengelolaan kekayaan daerah yang dipisahkan, dirinci menurut objek pendapatan yang mencakup bagian laba atas penyertaan modal pada perusahaan milik daerah/BUMD, bagian laba atas penyertaan modal pada perusahaan milik negara/BUMN dan bagian laba atas penyertaan modal pada perusahaan milik swasta atau kelompok masyarakat. Halim (2004) menyebutkan bahwa jenis pendapatan ini meliputi objek pendapatan berikut: a). Bagian laba perusahaan milik daerahb).Bagian laba lembaga keuangan bank.c).Bagian laba lembaga keuangan non bank. d). Bagian laba atas penyertaan modal/investasi]

\section{J. Lain-lain Pendapatan Asli Daerah Yang Sah}

Menurut UU No. 33 tahun 2004 menjelaskan tentang Pendapatan asli Daerah yang sah, disediakan untuk menganggarkan penerimaan daerah yang tidak termasuk dalam jenis pajak daerah, dan hasil pengelolaan kekayaan daerah yang dipisahkan. Halim (2004) menyebutkan jenis pendapatan ini meliputi objek pendapatan berikut; a) Hasil penjualan kekayaan daerah yang tidak dipisahkan b) Penerimaan Jasa Giroc) Pendapatan Bungad) Denda keterlambatan pelaksanaan pekerjaan e) Penerimaan ganti rugi atas kerugian/ kehilangan kekayaan daerah.

Halim (2004) membedakan 2 (dua) faktor yang mempengaruhi Pendapatan Asli Daerah suatu daerah, yaituFaktor Eksternal dan Faktor Internal. Faktor eksternal terdiri dari investasi, inflasi, PDRB dan jumlah penduduk, sedangkan faktor Internal terdiri dari sarana dan prasarana, insentif, penerimaan subsidi, penerimaan pembangunan, sumberdaya manusia, peraturan daerah, sistem dan pelaporan.

\section{METODE PENELITIAN}


Volume 19 Nomor 2

Jenis penelitian ini adalah bersifat deskriptif, yaitu usaha untuk menggambarkan dan menafsirkan data mengenai pola penerimaan asli daerah yang berimplikasi pada kontribusi PAD dalam APBD Pemerintah Daerah Kota Medan Tahun 2016-2018.

Penelitian ini menggunakan data sekunder yang diperoleh dari Organisasi Pemerintah Daerah: Badan Pengelola Keuangan dan Aset DaerahKota Medan. Data yang diambil dari tahun 2016 hingga tahun 2018adalah data Pendapatan Asli Daerah (PAD) yang terdapat di Pemerintah Kota Medan.

Metode analisis yang digunakan adalah analisis deskriptif.Variabel-variabel yang dianalisis yaitu laju pertumbuhan, kontribusi, dan perbedaan laju pertumbuhan dan kontribusi, penerimaan pajak dan retribusi daerah, hasil pengelolaan kekayaan daerah yang dipisahkan, lain-lain pendapatan asli daerah yang sah di Pemerintah Kota Medan yakni perhitungannya dengan menggunakan formula Fuad (2016)sebagai berikut :

\section{Pertumbuhan Pajak Daerah}

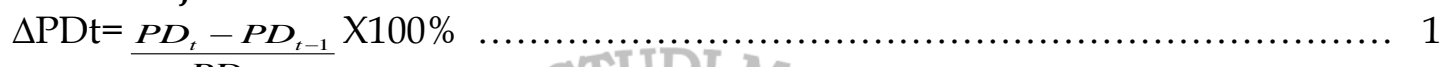

Keterangan :

$\triangle$ PDt : Laju Pertumbuhan Pajak Daerah .

PD : Pajak Daerah

$\mathrm{t}$ : Tahun tertentu

(t-1) : Tahun sebelumnya.

Pertumbuhan Retribusi Daerah

$$
\Delta \mathrm{RDt}=\frac{R D_{t}-R D_{t-1}}{R D_{t-1}} \times 100 \%
$$

Keterangan :

$\Delta$ RDt : Laju pertumbuhan Retribusi Daerah

RD : Retribusi Daerah

Pertumbuhan hasil pengelolaan kekayaan daerah yang dipisahkan $\triangle \mathrm{HPKDYD}=\underline{H P K D Y D_{t}>H P K D Y D_{t-1}} \mathrm{X} 100 \%$

Keterangan:

$$
H P K D Y D_{t \rightarrow 1} A T O L I K S A
$$

$\triangle$ HPKDYD= Laju pertumbuhan hasil pengelolaan kekayaan daerah yang dipisahkan

HPKDYD= hasil pengelolaan kekayaan daerah yang dipisahkan

Pertumbuhan lain-lain pendapatan asli daerah yang sah

$\Delta \mathrm{LLPADYS}=\frac{L L P A D Y S_{t}-L L P A D Y S_{t-1}}{L L P A D Y S_{t-1}} \times 100 \%$

Keterangan:

$\triangle$ LLPADYS= Laju pertumbuhan lain-lain pendapatan asli daerah yang sah

LLPADYS= lain-lain pendapatan asli daerah yang sah

\section{PEMBAHASAN}

Besarnya Pendapatan Asli Daerah dapat menjadi salah satu indikator dalam menilai peran dan kemampuan daerah dalam membiayai pembangunan dan rumah tangganya sendiri (self-supporting). PAD memiliki posisi strategis dalam proses pelaksanaan pembangunan daerah, karena digunakan untuk membiayai sebagian belanja pembangunan setiap tahunnya.

\section{A. Perbandingan Pendapatan Asli Daerah Kota Medan Tahun 2016-2017.}


Volume 19 Nomor 2

Perkembangan realisasi Pajak dan retribusi daerah Kota Medan untuk tahun angggaran 2016-2017 dapat dilihat dari Table 1.berikut:

Tabel 1. Perbandingan Penerimaan Pajak dan Retribusi Daerah Kota Medan Tahun Anggaran 2016-2017

\begin{tabular}{|c|c|c|c|c|}
\hline \multirow[t]{2}{*}{ No } & \multirow[t]{2}{*}{ URAIAN } & \multicolumn{3}{|c|}{ Penerimaan Asli Daerah } \\
\hline & & Thn Anggaran 2016 & $\begin{array}{l}\text { Thn Anggaran } \\
2017\end{array}$ & Persen \\
\hline [1] & [2] & [3] & {$[4]$} & [5] \\
\hline $\mathbf{I}$ & Pendapatan Asli Daerah & $1,535,721,173,386.31$ & 1.733.303.304.430,37 & 112.86 \\
\hline 1. & Pendapatan Pajak Daerah & $1,132,752,367,832.32$ & $1,407,150,734,319.73$ & 124.22 \\
\hline & a. Pajak Hotel & $95,822,427,293.65$ & $105,113,329,075.22$ & 109.70 \\
\hline & b. Pajak Restoran & $130,918,136,416.14$ & $148,377,522,764.68$ & 113.34 \\
\hline & c. Pajak Hiburan & $33,103,004,155.25$ & $36,433,396,238.34$ & 110.06 \\
\hline & d. Pajak Reklame & $17,508,256,230.32$ & $18,678,272,783.07$ & 106.68 \\
\hline & e. Pajak Penerangan Jalan & $228,208,022,998.00$ & $255,942,934,949.00$ & 112.15 \\
\hline & f. Pajak Parkir & $16,866,401,417.00$ & $18,686,075,970.20$ & 110.79 \\
\hline & g. Pajak BPHTB & $264,722,907,298.00$ & $449,118,558,909.00$ & 169.66 \\
\hline & h. Pajak Bumi dan Bangunan Perkotaan & $334,613,267,325.00$ & $363,261,342,254.00$ & 108.56 \\
\hline & i. Pajak Air Bawah Tanah & $10,989,944,698.96$ & $11,539,301,376.22$ & 105.00 \\
\hline & Pendapatan Retribusi Daerah & $115,597,958,126.00$ & $113,245,961,244.00$ & 97.97 \\
\hline 2.1 & Retribusi Jasa Umum & $49,982,792,847.00$ & $47,308,756,243.00$ & 94.650 \\
\hline & a. Retribusi Pelayanan Kesehatan & $228,559,000.00$ & $45,837,000.00$ & 20.055 \\
\hline & $\begin{array}{l}\text { b. Retribusi Pelayanan Persampahan/ } \\
\text { Kebersihan }\end{array}$ & $19,952,511,350.00$ & $19,221,150,650.00$ & 96.334 \\
\hline & $\begin{array}{l}\text { c. Retribusi Penggantian Biaya KTP dan Akte } \\
\text { Catatan Sipil }\end{array}$ & $761,995,000.00$ & $649,275,000.00$ & 85.207 \\
\hline & $\begin{array}{l}\text { d. Retribusi Pelayanan Pemakaman dan } \\
\text { Pengabuan Mayat }\end{array}$ & $278,645,000.00$ & $246,872,000.00$ & 88.597 \\
\hline & e. Retribusi Parkir Di Tepi Jalan Umum & $20,872,643,000.00$ & $19,744,361,583.00$ & 94.594 \\
\hline & $\begin{array}{lll}\text { f. Retribusi Pengujian Kendaraan } \\
\text { Bermotor }\end{array}$ & $6,274,575,000.00^{-}$ & $5,535,474,500.00$ & 88.221 \\
\hline & $\begin{array}{l}\text { g. Retribusi Pemeriksaan Alat Pemadam } \\
\text { Kebakaran }\end{array}$ & $1,611,893,000.00$ & $1,897,640,000.00$ & 117.727 \\
\hline & $\begin{array}{l}\text { h. Retribusi Penggantian Biaya Cetak } \\
\text { Peta }\end{array}$ & $1,971,497.00$ & $25,010.00$ & 1.269 \\
\hline & Retribusi Jasa Usaha & $3,276,078,025.00$ & 2,998,377,230.00 & 91.523 \\
\hline & $\begin{array}{lll}\text { a. Retribusi Pemakaian Kekayaan } \\
\text { Daerah }\end{array}$ & $1,876,387,025.00$ & $2,335,483,930.00$ & 124.467 \\
\hline & b. Retribusi Terminal & $1,363,281,000.00$ & $272,310,000.00$ & 19.975 \\
\hline & c. Retribusi Tempat Khusus Parkir & 0 & $121,667,417.00$ & \\
\hline & $\begin{array}{ll}\text { d. } & \text { Retribusi Tempat Rekreasi dan Olah } \\
\text { raga }\end{array}$ & $36,410,000.00$ & $37,760,000.00$ & 103.708 \\
\hline 2.3 & Retribusi Perizinan Tertentu & $62,339,087,254.00$ & $62,938,827,771.00$ & 100.962 \\
\hline & a. Retribusi Izin Mendirikan Bangunan & $43,771,442,397.00$ & $53,206,120,636.00$ & 121.554 \\
\hline & b. Retribusi Izin Gangguan/Keramaian & $18,187,514,357.00$ & $9,182,871,435.00$ & 50.490 \\
\hline & c. Retribusi Izin Trayek & $380,130,500.00$ & $274,543,500.00$ & 72.223 \\
\hline & $\begin{array}{l}\text { Retribusi Perpanjangan IMTA kepada } \\
\text { Pemberi Kerja Tenaga Kerja Asing - LRA }\end{array}$ & - & $681,140,600.00$ & - \\
\hline & $\begin{array}{l}\text { Pendapatan Hasil Pengelolaan Kekayaan } \\
\text { Daerah Yang Dipisahkan }\end{array}$ & $8,948,679,468.00$ & $6,095,561,295.00$ & 68.12 \\
\hline
\end{tabular}


Volume 19 Nomor 2

\begin{tabular}{|c|c|c|c|c|}
\hline \multirow[t]{2}{*}{ No } & \multirow[t]{2}{*}{ URAIAN } & \multicolumn{3}{|c|}{ Penerimaan Asli Daerah } \\
\hline & & Thn Anggaran 2016 & $\begin{array}{l}\text { Thn Anggaran } \\
2017\end{array}$ & Persen \\
\hline [1] & [2] & [3] & {$[4]$} & [5] \\
\hline & $\begin{array}{l}\text { a. Bagian Laba Penyertaan Modal pada } \\
\text { Perusahaan Milik Daerah/BUMD }\end{array}$ & $766,611,703.00$ & $135,295,070.00$ & 17.65 \\
\hline & $\begin{array}{l}\text { b. Bagian Laba Penyertaan Modal pada } \\
\text { Perusahaan Milik Negara/BUMN }\end{array}$ & $8,182,067,765.00$ & $5,960,266,225.00$ & 72.85 \\
\hline & $\begin{array}{l}\text { Lain-Lain Pendapatan Asli Daerah Yang } \\
\text { Sah }\end{array}$ & $278,422,167,959.00$ & $206,811,047,571.64$ & 74.28 \\
\hline & a. Penerimaan Jasa Giro & $17,473,131,733.00$ & $12,123,131,801.00$ & 69.38 \\
\hline & b. Pendapatan Denda Pajak & $2,296,152,917.91$ & $1,577,982,508.78$ & 68.72 \\
\hline & c. Pendapatan Dari Pengembalian & $36,787,827,927.98$ & $14,626,277,055.32$ & 39.76 \\
\hline & d. Pendapatan BLUD RS. Dr. Pirngadi & $140,762,750,221.10$ & $106,012,392,496.54$ & 75.31 \\
\hline & e. Dana Kapitasi JKN pada FKTP & $278,422,167,959.00$ & $72,471,263,710.00$ & 26.03 \\
\hline
\end{tabular}

Sumber:Diolah diolah

Dari Table 1 di atas tampak bahwa penerimaan pajak daerah Kota Medan mengalami peningkatan sebesar 24.22 persen pada tahun 2017 jika dibandingkan dengan tahun 2016. Peningkatan pajak daerah pada tahun 2017 bersumber dari pajak hotel sebesar 9.7 persen, pajak restoran sebesar 13.34 persen, pajak hiburan sebesar 10.06 persen, pajak reklame sebesar 6.68 persen, pajak penerangan jalan sebesar 12.15 persen, pajak parkir sebesar 10.79 persen, Bea Perolehan Hak Atas Tanah dan Bangunan sebesar 69.66 persen, pajak bumi dan bangunan perkotaan sebesar 8.56 persen dan pajak bawah air tanah sebesar 5 persen. Meningkatnya realisasi pendapatan pajak daerah tahun 2017 jika dibandingkan dengan tahun 2016 menunjukkan bahwa aktivitas ekonomi Kota Medan terus mengalami peningkatan dari waktu ke waktu, yang dïringi dengan usaha dalam menggali sumber-sumber potensial penerimaan pajak daerah. Tingginya realisasi dari hasil pajak daerah juga menunjukkan bahwa masyarakat dan dunia usaha Kota Medan telah sadar dan berperan serta aktif dalam upaya pembangunan Kota Medan. Pendapatan retribusi daerah Kota Medan mengalami penurunan pada tahun 2017 jika dibandingkan tahun 2016 sebesar2.03 persen. Penerimaan retribusi daerah Kota Medan mengalami penurunan sebesar 2,03 persen pada tahun 2017 jika dibandingkan dengan tahun 2016. Penurunan penerimaan distribusi daerah ini bersumber dari retribusi jasa umum sebesar 5.35 persen dan retribusi jasa usaha sebesar 8.48 persen, walapaun retribusi perijinan tertentu hanya mengalami peningkatan sebesar 0.96 persen. Penerimaan hasil pengelolaan kekayaan daerah yang dipisahkan daerah Kota Medan mengalami penurunan sebesar 31,88 persen pada tahun 2017 jika dibandingkan dengan tahun 2016. Penurunan penerimaan dari hasil pengelolaan kekayaan daerah yang dipisahkan berasal dari bagian laba penyertaan sebesar 82,35 persen dan bagian laba penyertaan modal pada perusahaan Milik Negara/BUMN sebesar 27,15 persen. Lain-lain pendapatan asli daerah yang sah mengalami penurunan pada tahun 2017 dibandingkan tahun 2016 sebesar 25,72 persen. Penurunan Lain-lain Pendapatan Asli Daerah yang Sah pada tahun 2017 dibandingkan tahun 2016 berasal dari: (1) Jasa Giro mengalami penurunan sebesar 30,62 persen; (2) Pendapatan Denda Pajak mengalami penurunan sebesar 31,28 persen; (3) Pendapatan Denda mengalami penurunan sebesar 60,24 persen (4) Pendapatan BLUD mengalami penurunan sebesar 24,69 persen, dan (5) Dana Kapitasi JKN pada FKTP mengalami penurunan sebesar 73,97 persen.

\section{B. Perbandingan Pendapatan Asli Daerah Kota Medan Tahun 2016-2017.}

Perbandingan realisasi Pajak dan retribusi daerah Kota Medan untuk tahun angggaran 2018-2017 dapat dilihat dari table 2.berikut: 
Tabel 2 Perbandingan Penerimaan Pajak dan Retribusi Daerah Kota Medan Tahun Anggaran 2017-2018

\begin{tabular}{|c|c|c|c|c|}
\hline \multirow{2}{*}{ No } & \multirow{2}{*}{ URAIAN } & \multicolumn{2}{|c|}{ Penerimaan Asli Daerah } & \multirow[t]{2}{*}{ Persen } \\
\hline & & Tahun Anggaran 2017 & Tahun Anggaran 2018 & \\
\hline [1] & [2] & {$[3]$} & {$[4]$} & [5] \\
\hline \multicolumn{2}{|c|}{ A. Pendapatan Asli Daerah } & $1,733,303,304,430.37$ & $1,640,219,564,624.26$ & 94.63 \\
\hline & a. Pajak Hotel & $105,113,329,075.22$ & $119,664,695,854.00$ & 113.84 \\
\hline & b. Pajak Restoran & $148,377,522,764.68$ & $172,788,503,072.00$ & 116.45 \\
\hline & c. Pajak Hiburan & $36,433,396,238.34$ & $43,079,908,039.00$ & 118.24 \\
\hline & d. Pajak Reklame & $18,678,272,783.07$ & $13,727,520,958.00$ & 73.49 \\
\hline & e. Pajak Penerangan Jalan & $255,942,934,949.00$ & $278,135,298,509.00$ & 108.67 \\
\hline & f. Pajak Parkir & $18,686,075,970.20$ & $22,209,803,703.00$ & 118.86 \\
\hline & g. Pajak Bumi dan Bangunan (PBB) & $363,261,342,254.00$ & $382,408,222,844.00$ & 105.27 \\
\hline & h. Pajak BPHTB & $449,118,558,909.00$ & $275,741,255,103.00$ & 61.40 \\
\hline & i. Pajak Air Tanah & $11,539,301,376.22$ & $11,187,845,209.00$ & 96.95 \\
\hline \multirow[t]{21}{*}{2} & \begin{tabular}{|c|} 
Hasil Retribusi Daerah \\
\end{tabular} & $113,245,961,244.00$ & $85,204,885,174.00$ & 75.24 \\
\hline & a. Retribusi Jasa Umum & $47,308,756,243.00$ & $49,414,598,080.00$ & 104.45 \\
\hline & 1. Retribusi Pelayanan Kesehatan & $45,837,000.00$ & $20,290,000.00$ & 44.27 \\
\hline & $\begin{array}{l}\text { 2. Retribusi Pelayanan Persampahan / } \\
\text { Kebersihan }\end{array}$ & $19,221,150,650.00$ & $20,542,478,300.00$ & 106.87 \\
\hline & $\begin{array}{l}\text { 3. Retribusi Penggantian Biaya KTP dan Akte } \\
\text { Catatan Sipil }\end{array}$ & $649,275,000.00$ & $740,120,000.00$ & 113.99 \\
\hline & $\begin{array}{l}\text { 4. Retribusi Pelayanan Pemakaman dan } \\
\text { Pengabuan Mayat }\end{array}$ & $246,872,000.00$ & $312,080,000.00$ & 126.41 \\
\hline & 5. Retribusi Parkir Di Tepi Jalan Umum & $19,744,361,583.00$ & $19,719,411,000.00$ & 99.87 \\
\hline & 6. Retribusi Pengujian Kendaraan Bermotor & $5,535,474,500.00$ & $5,795,791,500.00$ & 104.70 \\
\hline & $\begin{array}{l}\text { 7. Retribusi Pemeriksaan Alat Pemadam } \\
\text { Kebakaran }\end{array}$ & $1,897,640,000.00$ & $2,003,580,000.00$ & 105.58 \\
\hline & 8. Retribusi Penggantian Biaya Cetak Peta & $25,010.00$ & 0.00 & 0.00 \\
\hline & 9. Retribusi Jasa Umum Tera Ulang & & $280,847,280.00$ & \#DIV/0! \\
\hline & b.Retribusi Jasa Usaha & $2,998,377,230.00$ & $7,382,853,485.00$ & 246.23 \\
\hline & $\begin{array}{l}\text { 1. Retribusi Pemakaian Kekayaan } \\
\text { Daerah }\end{array}$ & $2,335,483,930.00$ & $6,560,364,485.00$ & 280.90 \\
\hline & 2. Retribusi Terminal & $272,310,000.00$ & $279,133,000.00$ & 102.51 \\
\hline & 3. Retribusi Tempat Khusus Parkir & $121,667,417.00$ & $538,356,000.00$ & 442.48 \\
\hline & $\begin{array}{l}\text { 4. Retribusi Tempat Rekreasi dan Olah } \\
\text { raga }\end{array}$ & $37,760,000.00$ & $5,000,000.00$ & 13.24 \\
\hline & c.Retribusi Perizinan Tertentu & $62,938,827,771.00$ & $28,407,433,609.00$ & 45.13 \\
\hline & 1. Retribusi Izin Mendirikan Bangunan & $53,206,120,636.00$ & $25,753,256,509.00$ & 48.40 \\
\hline & 2. Retribusi Izin Gangguan/Keramaian & $9,182,871,435.00$ & & 0.00 \\
\hline & 3. Retribusi Izin Trayek & $274,543,500.00$ & $215,319,100.00$ & 78.43 \\
\hline & $\begin{array}{l}\text { 4. Retribusi Perpanjangan IMTA kepada } \\
\text { Pemberi Kerja Tenaga Kerja Asing - LRA }\end{array}$ & $681,140,600.00$ & $2,438,858,000.00$ & 358.06 \\
\hline \multirow[t]{3}{*}{3} & $\begin{array}{l}\text { Pendapatan Hasil Pengelolaan } \\
\text { Kekayaan Daerah Yang Dipisahkan }\end{array}$ & $6,095,561,295.00$ & $11,901,953,037.00$ & 195.26 \\
\hline & $\begin{array}{l}\text { b. Bagian Laba Penyertaan Modal pada } \\
\text { Perusahaan Milik Daerah/BUMD }\end{array}$ & $135,295,070.00$ & $917,502,382.00$ & 678.15 \\
\hline & $\begin{array}{l}\text { c. Bagian Laba Penyertaan Modal pada } \\
\text { Perusahaan Milik Negara/BUMN }\end{array}$ & $5,960,266,225.00$ & $10,984,450,655.00$ & 184.29 \\
\hline \multirow[t]{5}{*}{4} & $\begin{array}{l}\text { Lain-Lain Pendapatan Asli Daerah Yang } \\
\text { Sah }\end{array}$ & $206,811,047,571.64$ & $224,169,673,122.26$ & 108.39 \\
\hline & a. Penerimaan Jasa Giro & $12,123,131,801.00$ & $9,104,877,911.00$ & 75.10 \\
\hline & b. Pendapatan Denda Pajak & $1,577,982,508.78$ & $1,767,992,813.29$ & 112.04 \\
\hline & c. Pendapatan Dari Pengembalian & $14,626,277,055.32$ & $25,517,358,812.05$ & 174.46 \\
\hline & d. Pendapatan BLUD RS. Dr. Pirngadi & $106,012,392,496.54$ & $104,363,212,285.92$ & 98.44 \\
\hline
\end{tabular}


Dari Table 2 di atas tampak bahwa penerimaan pajak daerah Kota Medan mengalami penurunan sebesar 5.37 persen pada tahun 2018 jika dibandingkan dengan tahun 2017. Penurunan pajak daerah pada tahun 2018 pajak reklame sebesar 26.55 persen, pajak BPHTB sebesar 38.60 persen, pajak air tanah sebesar 24.76 persen, walapun beberapa pajak yang lain mengalami peningkatan yakni dari pajak hotel sebesar 13.84 persen, pajak restoran sebesar 16.45 persen, pajak hiburan sebesar 18.24 pajak penerangan jalan sebesar 8.67 persen, pajak parkir sebesar 11.86 persen, pajak bumi dan bangunan perkotaan sebesar 5.27 persen. Penurunan realisasi pendapatan pajak daerah tahun 2018 jika dibandingkan dengan tahun 2017 menunjukkan bahwa aktivitas ekonomi Kota Medan mengalami stagnan pada tahun 2018.

Pendapatan retribusi daerah mengalami penurunan pada tahun 2018 jika dibandingkan tahun 2017 sebesar 224.76 persen. Penurunan penerimaan distribusi daerah ini bersumber dari retribusi perijinan tertentu sebesar 54.87 persen, walaupun peningkatan dari penerimaan retribusi jasa umum sebesar 4.45 persen dan retribusi jasa usaha sebesar 146.23 persen. Penerimaan hasil pengelolaan kekayaan daerah yang dipisahkan daerah Kota Medan mengalami peningkatan sebesar 95,25 persen pada tahun 2018 jika dibandingkan dengan tahun 2017. Peningkatanpenerimaan dari hasil pengelolaan kekayaan daerah yang dipisahkan berasal dari bagian laba penyertaan sebesar 578,15 persen dan bagian laba penyertaan modal pada perusahaan Milik Negara/BUMN sebesar 84,29 persen. Lain-lain pendapatan asli daerah yang sah mengalami peningkatan pada tahun 2018 dibandingkan tahun 2017 sebesar 8,29 persen. Peningkatan Lain-lain Pendapatan Asli Daerah yang Sah pada tahun 2018 dibandingkan tahun 2017 berasal dari: (1) Pendapatan Denda Pajak mengalami peningkatan sebesar 12,04 persen; (2) Pendapatan Denda mengalami penurunan sebesar 74,46 persen; (3) Dana Kapitasi JKN pada FKTP mengalami penurunan sebesar 15,10 persen, walapaun, (1) Jasa Giro mengalami penurunan sebesar 30,62 persen dan (2) Pendapatan BLUD mengalami penurunan sebesar 24,69 persen

\section{KESIMPULAN DAN SARAN}

\section{A. Kesimpulan}

Berdasarkan hasil analisis dan pembahasan maka dapat disimpulkan bahwa: untuk tahun anggaran 2017/2016 bahwa realisasi pajak daerah mengalami peningkatan sebesar 24,22 persen, retribusi daerah mengalami penurunan sebesar 2,03persen, pendapatan hasil pengelolaan kekayaan daerah yang dipisahkan mengalami penurunan sebesar 31,88 persen, dan lain-lain pendapatan asli daerah yang sah mengalami penurunan sebesar 25,72 persen, sedangkan untuk tahun anggaran 2018/2017 menunjukkan bahwa realisasi pajak daerah mengalami penurunan sebesar 6,27 persen, retribusi daerah mengalami penurunan sebesar 24,76persen, pendapatan hasil pengelolaan kekayaan daerah yang dipisahkan mengalami peningkatan sebesar 95,26 persen, dan lain-lain pendapatan asli daerah yang sah mengalami peningkatan sebesar 8,39 persen

\section{b. Saran}

Berdasarkan kesimpulan yang diperoleh,maka bagi Pemerintah Kota Medandianjurkan adalah sebagai berikut:

1. Mengoptimalkan usaha dalam peningkatan pendapatan pajak daerah maka diperlukan sosialisasi, pengawsan, koordinasi, dan pendataanulang terhadap potensi atau omzet wajib pajak, Menyampaikan surat teguran kepada wajib pajak yang tidak/terlambat menyampaikan SPTPD, Melaksanakan penagihan langsung kepada wajib pajak, 


\section{Volume 19 Nomor 2}

Melaksanakan verifikasi/pemeriksaan terhadap wajib pajak, Melaksanakan pendataan dan pendaftaran bagi wajib pajak baru.

2. Meningkatan penerimaan retribusi daerah salah satunya dengan cara mengadakan sosialisasi, koordinasi dengan aparat dan OPD terkait agar masyarakat dan investor lebih tertarik menanamkan modalnya serta penegakan Peraturan daerah tentang retribusi Pemerintah Kota Medan.

\section{DAFTAR PUSTAKA}

Halim, Abdul, 2012. Akuntansi Sektor Publik, Akuntansi Keuangan Daerah. Salemba Empat, Jakarta.

Jumingan, 2000.Analisis Laporan Keuangan. Jakarta: BumiAksara.Komite Standar

Mardiasmo, 2004.Akuntansi Sektor Publik. BPFE, Yogyakarta:

Moh. Ramli, Fuad, 2016. Analisis Laporan Keuangan Pemerintah Daerah. Ghalia Indonesia, Bogor

Undang-undang Republik Indonesa Nomor 17 Tahun 2003 tentang Keuangan Negara.

Undang - Undang Nomor 23 Tahun 2014 tentang Pemerintahan Daerah.

Undang - Undang Nomor 28 tahun 2009 tentang Pajak Daerah dan Retribusi Daerah

Peraturan Pemerintah Nomor 18 Tahun 2016 tentang Organisasi Perangkat Daerah;

Rencana Strategis Tahun 2016-2021 Badan Pajak dan Retribusi Daerah Kota Medan

Peraturan Daerah No 15 Tahun 2016 Tentang Pembentukan Struktur Perangkat Daerah Kota Medan.

Peraturan Daerah Kota Medan Nomor 9 Tahun 2009, Nomor 12 Tahun 2012, Nomor 2 Tahun 2014, Nomor 3 Tahun 2015, Nomor 3 Tahun 2016, Nomor 6 Tahun 2016 dan Nomot 7 Tahun 2016 tentang Retribusi Daerah Kota Medan

Saragih, Juli Panglima, 2003. Desentralisasi Fiskal dan Keuangan Daerah Dalam Otonomi. Ghalia Indonesia, Jakarta 